\title{
Palynological characterization and genetic divergence between accessions of chilli and sweet peppers
}

\author{
Kellen C Martins ${ }^{1}$; Sérgio Alessandro M Souza ${ }^{1}$; Telma Nair S Pereira ${ }^{1}$; Rosana Rodrigues ${ }^{1}$; Messias G \\ Pereira'; Maura Da Cunha ${ }^{2}$ \\ ${ }^{1}$ UENF-LMGV, Av. Alberto Lamego 2000, Parque Califórnia, 28015-620 Campos dos Goytacazes-RJ; kellen.coutinho@hotmail.com; \\ sergiobioufpel@yahoo.com; telmasp2012@gmail.com; rosana@uenf.br; messias@uenf.br; 2UENF-LBCT; maura@uenf.br
}

\begin{abstract}
This study characterised pollen grains morphologically and studied the genetic divergence between accessions based on morphopollinic characters. Seven accessions, including domesticated, semi-domesticated and wild species of Capsicum (C. annuum var. annuum, C. chinense, C. baccatum var. pendulum, C. frutescens, Capsicum annuum var. glabriusculum, C. baccatum var. baccatum and C. parvifolium), were cultivated in a greenhouse and their pollen grains collected and fixed during flowering. The pollen grains were acetolysed and described based on 13 pollinic characteristics (polar and equatorial axes, in an equatorial front view; ratio between polar axis and equatorial axis; equatorial axis in a polar view; thicknesses of the exine, sexine and nexine; apocolpus side; polar area index; length and diameter of the pore and colpus). The genetic divergence analysis between the accessions was based on the standardised average Euclidean distance, and the grouping analysis was based on Ward's method. PCA (principal component analysis) is another multivariate method that was used. Based on Ward's method and PCA, it was possible to group the accessions into two groups, and the groups formed correlated with the classification of the gene pool complexes already described for the genus. According to this classification, the Capsicum genus comprises three major groups: $C$. annuum, $C$. chinense and $C$. frutescens form the annuum complex; C. baccatum and C. pratermissum form the baccatum complex; and C. eximium, $C$. cardenasii and $C$. pubescens form the pubescens complex. The variable width of the pores was the most discriminating in this morphopollinic study of Capsicum spp.
\end{abstract}

Keywords: Solanaceae, Capsicum spp., multivariate analysis, pollen grains.

\section{RESUMO}

Caracterização palinológica e divergência genética entre acessos de pimenta e pimentão

O presente trabalho teve por objetivos caracterizar morfologicamente os grãos de pólen e estudar a divergência genética entre os acessos, com base nos caracteres morfopolínicos. Sete acessos representantes de espécies domesticadas, semidomesticadas e silvestres de Capsicum (C. annuum var. annuum, C. chinense, C. baccatum var. pendulum, $C$. frutescens, Capsicum annuum var. glabriusculum, $C$. baccatum var. baccatum e C. parvifolium) foram cultivados em casa de vegetação e no florescimento, grãos de pólen foram coletados e fixados. Posteriormente, os grãos de pólen foram acetolisados e descritos com base em 13 características polínicas (eixo polar e equatorial em vista equatorial; razão entre eixo polar e equatorial; eixo equatorial em vista polar; espessura da exina, sexina e nexina; lado do apocolpo; índice de área polar; comprimento e diâmetro do poro e do colpo). A análise da divergência genética entre os acessos foi realizada utilizando a distância Euclidiana Média Padronizada e a análise de agrupamento pelo método de Ward. A análise dos componentes principais (ACP) foi outro método de análise multivariada utilizado. Pelos métodos de Ward e ACP os acessos foram agrupados em dois grupos de acordo com classificação dos complexos gênicos já descritos para o gênero. De acordo com essa classificação, o gênero Capsicum compreende três grupos principais: $C$. annuum, $C$. chinense e $C$. frutescens formam o complexo annuum; $C$. baccatum e C. pratermissum formam o complexo baccatum; e C. eximium, $C$. cardenasii e $C$. pubescens formam o complexo pubescens. A variável largura do poro foi a mais discriminante para o estudo morfopolínico de Capsicum spp.

Palavras-chave: Solanaceae, Capsicum spp., análise multivariada, grãos de pólen.

(Recebido para publicação em 25 de fevereiro de 2013; aceito em 14 de outubro de 2013) (Received on February 25, 2013; accepted on October 14, 2014)

$\mathrm{T}^{\mathrm{s}, \mathrm{c}}$ Capsicum genus includes approximately 30 species represented by 25 wild and 5 domesticated species that originate from tropical America (Moscone et al., 2007). The diversity observed in the genus is broad, with a variety of forms, sizes, colours, fruit flavours and nutritional compositions (Bosland \& Votava, 2012).

The study of the genetic variability in chili pepper and sweet pepper species allows the identification of possible fertile breeding between distinct types and the transference of genes of interest between different genotypes. The diversity information on domesticated Capsicum species represents an easier and simpler opportunity to use germplasm in inter-specific and intraspecific breeding program.
Genetic variability can be studied with different methodologies, such as those employing morphoagronomic descriptors (Costa et al., 2009; Sudré et al., 2005), molecular markers, meiotic analysis (Martins et al., 2010), karyotype analysis (Souza et al., 2011), disease resistance (Riva et al., 2007) and palynological characters (Kumar et al., 1986; Raghuvanshi, 1977). 
Because of their great morphological diversity, pollen grains are important for taxonomic purposes; through palynological studies, they have increasingly been used in recent decades as auxiliary support for the taxonomic classification of plant groups, generating phylogenetic clades that more precisely express the origin and evolution of organisms (Judd et al., 2007).

The significance of pollen morphology in plant systematics has been stressed by various researchers. According to Stuessy (2009), data from pollen grains are known to be useful at all levels of the taxonomic hierarchy (generic, subgeneric, interspecific and intra-specific level), and can often be helpful in suggesting relationship on numerous occasions. The study of pollinic morphology generates information on genetic identity and parentage of genotypes, which is important for the exploration of germplasms aimed at maximizing the use of genetic diversity (He et al., 1995).

Thus, the present study contributes to the knowledge of the genetic diversity in the genus Capsicum based on the study of pollinic morphology in several domesticated, semi-domesticated and wild Capsicum species, and it verifies genetic relationships between these species based on the quantitative characteristics of pollen identified through multivariate analysis.

\section{MATERIAL AND METHODS}

Seven Capsicum accessions were used in the study, six of which were either domesticated or semi-domesticated species, from UENF (Universidade Estadual do Norte Fluminense Darcy Ribeiro) germplasm collection: $C$. annuum var. annuum (UENF 1562), $C$. chinense (UENF 1785), C. baccatum var. pendulum (UENF 1624), C. frutescens (UENF 1636), Capsicum annuum var. glabriusculum (UENF 1559) and C. baccatum var. baccatum (UENF 1495). The wild species was C. parvifolium (CNPH 3331), kindly donated by Centro Nacional de Pesquisa de Hortaliças/ Empresa Brasileira de Pesquisas Agropecuárias. Each species was represented in the study by 10 plants.

Seeds from each accession were planted in germination chamber at $27.5^{\circ} \mathrm{C}$ under a photoperiod of $8 \mathrm{~h}$ light/ $16 \mathrm{~h}$ dark and later cultivated in $5-\mathrm{L}$ pots in a protected environment. At least two flowers per plant were collected in the mornings for pollinic morphology analysis. At anthesis, the anthers of these flowers were acetolysed according to the method described by Erdtman (1960).

The pollen grains were measured from the polar and equatorial axes, in an equatorial front view, and the equatorial axis and in a polar view. The length and diameter of the apertures (pore and colpus) were also measured, as were the thicknesses of the exine layers (sexine and nexine), and apocolpium. The palynological descriptions were based on the nomenclature of Erdtman (1952), Barth \& Melhem (1988) and Punt et al. (2007). Twenty-six measurements were randomly taken from various slides for each of the examined pollen characteristics; at least five pollen grains were measured per slide.

The average $(\mu)$, variation interval (FV), standard deviation(s), coefficient of variation $(\mathrm{CV})$, and confidence interval at $95 \%$ probability were calculated for the measurements of the equatorial and polar diameter, apocolpus side, and sub-layers of the pollen grain wall. The acetolysed pollen grains were examined using an Olympus BX60 optical microscope, and the images were captured, analysed and measured using the Image-Pro Plus version 5.1 program.

The composition of the groups formed by similar accessions was determined by the hierarchical grouping of Ward's method using the standardised average Euclidean distance as the dissimilarity measure with the aid of the GENES (Cruz, 2006) and R (http:// www.rproject.org) software programs. PCA is another multivariate method that was used to estimate the genetic divergence of the Capsicum accessions.

\section{RESULTS AND DISCUSSION}

The average values of the measurements are listed in Table 1.
The morphopollinic results allowed the characterization of the pollen grains from the Capsicum genus as small (C. annuum var. annuum, C. baccatum var. pendulum and $C$. baccatum var. baccatum) and medium (C. chinense, C. frutescens, C. annuum var. glabriusculum and C. parvifolium), according to Erdtman (1986), who establish that the pollen grains from the Solanaceae vary from small $(14.5 \mu \mathrm{m})$ to large $(61 \mu \mathrm{m})$. Salgado-Labouriau (1973) observed greater axis values ranging from 10 to $80 \mu \mathrm{m}$ for Solanaceae species from Brazilian Cerrado region, which indicates that the values observed for the Capsicum pollen grains in this study are within the range observed for the other genera in this family.

The polar area varied from small to large (PAI 0.43-0.58 $\mu \mathrm{m}$ ) (Figure 1 and Table 1), these sizes do not agree to the polar areas observed in other Solonaceae species such as Solanum spp. (Franklim \& Esteves, 2008). These differences show that the pollen grains of all Solanaceae members are not identical, and therefore, Solanaceae is considered a eurypalynous family.

The pollen grains can be classified as isopolar with similar proximal and distal poles with a triangular to subcircular amb, and as having radial symmetry. The apertures, always present in groups of three, were composites and characterized by a colpus that had a circular lalongate endoaperture (transversely elongated) called a pore, which characterizes the pollen grains as tricolpate. The colpi ranged from short to long (Table 2) and possessed irregular contours and rounded extremities.

The characteristics observed in this study are in accordance with the description of Solanum spp., which have isopolar and radially symmetrical pollen grains (Lashin, 2012), and with the description of species in the Solanaceae family from the cerrado, in which, despite the different types of pollen grains, the ones showing triapertures, with large os and lalongate shape are prevalent (Salgado-Labouriau, 1973). In a palynological study of 21 taxa of Solanum that occurred on a sandbank in Rio de Janeiro State, Franklim \& Esteves (2008) classified several species based 
Table 1. Quantitative data of pollen grains of accessions of Capsicum (dados quantitativos dos grãos de pólen dos acessos de Capsicum). Campos dos Goytacazes, UENF, 2010.

\begin{tabular}{lrrrrrrr}
\hline \multirow{2}{*}{ Variable $^{1}$} & \multicolumn{7}{c}{ Accessions } \\
\cline { 2 - 8 } & $\mathbf{1 5 6 2}$ & $\mathbf{1 5 5 9}$ & $\mathbf{1 4 9 5}$ & $\mathbf{1 6 2 4}$ & $\mathbf{1 7 8 5}$ & $\mathbf{1 6 3 6}$ & \multicolumn{1}{c}{$\mathbf{3 3 3 1}$} \\
\hline E (VE) & 22.977 & 24.607 & 22.973 & 23.862 & 24.786 & 24.520 & 24.860 \\
P (VE) & 23.955 & 26.661 & 22.796 & 24.735 & 26.020 & 25.757 & 26.273 \\
E (VP) & 20.191 & 23.456 & 22.973 & 22.358 & 20.280 & 21.898 & 22.910 \\
P/E & 1.043 & 1.083 & 0.991 & 1.038 & 1.050 & 1.052 & 1.057 \\
Apocolpium & 8.885 & 13.078 & 13.07 & 13.114 & 7.667 & 10.951 & 13.196 \\
PAI & 0.438 & 0.555 & 0.588 & 0.587 & 0.378 & 0.499 & 0.576 \\
Colpus length & 19.521 & 21.534 & 21.207 & 19.522 & 20.789 & 20.495 & 21.745 \\
Colpus diameter & 2.298 & 2.278 & 2.013 & 1.948 & 2.434 & 2.139 & 1.805 \\
Pore length & 6.459 & 6.494 & 8.177 & 7.174 & 6.770 & 7.621 & 7.788 \\
Pore diameter & 8.451 & 9.514 & 10.776 & 10.490 & 8.490 & 9.506 & 11.036 \\
Exine & 1.283 & 1.186 & 1.059 & 1.095 & 1.162 & 1.234 & 1.061 \\
Sexine & 0.660 & 0.603 & 0.608 & 0.637 & 0.596 & 0.624 & 0.603 \\
Nexine & 0.622 & 0.583 & 0.451 & 0.458 & 0.566 & 0.609 & 0.458 \\
IC & 8.450 & 9.510 & 10.490 & 10.770 & 8.490 & 9.500 & 11.030 \\
\hline
\end{tabular}

${ }^{1} \mathrm{E}=$ equatorial diameter (diâmetro equatorial), $\mathrm{P}=$ polar diameter (diâmetro polar), $\mathrm{VE}=$ equatorial view (vista equatorial), $\mathrm{VP}=$ polar view (vista polar), $\mathrm{P} / \mathrm{E}=$ ratio between polar axis and equatorial axis (razão entre o eixo polar e o eixo equatorial), $\mathrm{PAI}=$ polar area index (índice de área polar), $\mathrm{IC}=$ confidence interval at $95 \%$ (intervalo de confiança a $95 \%$ ). C. annuum var. annuum (UENF 1562), C. annuum var. glabriusculum (UENF 1559), C. baccatum var. pendulum (UENF 1624), C. baccatum var. baccatum (UENF 1495), C. chinense (UENF 1785), C. frutescens (UENF 1636) e C. parvifolium (CNPH 3331).

primarily on the peculiarities of the endoaperture. However, all 21 species possessed lalongate endoapertures and were tricolpates.

In this study, the colpi were equidistantly distributed around the equator of the grain in all studied species (trizonocolpates), which was the same aperture type observed by Barth \& Duarte (2008) in nine tree Solanaceae species from the Acnistus, Aureliana, Brunfelsia, Capsicum, Cestrum, and Solanum genera.

Analyses of the endoaperture width values based on the confidence interval, showed that they do not inter-penetrate except $C$. annuum var. annuиm and $C$. chinense, which show endoaperture values close and distinct from the others. The endoaperture width values varied from 8.45 (C. annuum var. annuum) to 11.03 (C. parvifolium) (Table 1).

The studied species had prolate spheroidal or oblate spheroidal pollen grain shapes; the latter shape was observed only in C. baccatum var. baccatum (Table 2). The shape of the pollen grain in the species Capsicum schottianum var. flexuosum was identified by Barth \& Duarte (2008) as subprolate, which, according to Erdtman (1952), can be classified as sub-spheroidal, along with suboblate, oblate spheroidal, spherical, and prolate spheroidal.

In the species $C$. annuum var. annuum (UENF 1562), the exine was between $1.05 \mu \mathrm{m}$ and $1.28 \mu \mathrm{m}$, which was the smallest measurement recorded. The subdivisions of the exine (sexine and nexine) showed similar values in $C$. annuum and its varieties, $C$. chinense and $C$. frutescens, whereas in C. parvifolium and C. baccatum and its varieties, the outer pollen wall was always thicker than the inner pollen wall (Table 1).

According to Perveen \& Qaiser (2007), sexine as thick as nexine, or slightly thicker or thinner than nexine were observed in 20 species representing seven genera of the Solanaceae. However, in Capsicum schottianum, the sexine is much thicker than the nexine (Barth \& Duarte, 2008). When analysing the pollinic morphology of some species of Solanum genus, Al-Wadi \& Lashin (2007) observed that, in all the species, the sexine is thicker than the nexine.

All Capsicum species studied here had foveolate exines; Willard et al. (2004) also observed this type of exine in pollen grains of Capsicum annuиm, corroborating our results. However, the data on the ornamentation of the exine varies among the studied species of Solanaceae: striated, reticulated, and granulated pollen grains have all been observed in this family (Erdtman, 1986).

By multivariate analysis and using the standardised average Euclidean,

Table 2. Descriptions of pollen grains of accessions studied in the genera Capsicum (descrição dos grãos de pólen dos acessos estudados no gênero Capsicum). Campos dos Goytacazes, UENF, 2010.

\begin{tabular}{llllll}
\hline Accessions & Amb & Shape & Polar area & Colpus & Exine \\
\hline UENF 1562 & Triangular & prolate spheroidal & Small & Long & Foveolate \\
UENF 1559 & Sub-circular & prolate spheroidal & Large & Short & Foveolate \\
UENF 1495 & Sub-circular & oblate spheroidal & Large & Short & Foveolate \\
UENF 1624 & Sub-circular & prolate spheroidal & Large & Short & Foveolate \\
UENF 1785 & Triangular & prolate spheroidal & Small & Long & Foveolate \\
UENF 1636 & Triangular & prolate spheroidal & Small & Long & Foveolate \\
CNPH 3331 & Sub-circular & prolate spheroidal & Large & Short & Foveolate \\
\hline
\end{tabular}


Table 3. Standardised average Euclidean distances between the accessions (distância euclidiana media padronizada entre os acessos). Campos dos Goytacazes, UENF, 2010.

\begin{tabular}{|c|c|c|c|c|c|c|c|}
\hline Accessions & 1562 & 1559 & 1624 & 1495 & 1785 & 1636 & 3331 \\
\hline UENF 1562 & & 1.655154 & 1.709436 & 1.696363 & 1.257897 & 1.142602 & 2.103866 \\
\hline UENF 1559 & & & 1.286172 & 1.707526 & 1.263671 & 892035 & 1.123823 \\
\hline UENF 1495 & & & & 1.020125 & 1.656112 & 1.016243 & 0.752432 \\
\hline UENF 1624 & & & & & 1.830099 & 1.437289 & 1.38881 \\
\hline UENF 1785 & & & & & & .995304 & 1.68202 \\
\hline UENF 1636 & & & & & & & 1.172668 \\
\hline CNPH 3331 & & & & & & & \\
\hline
\end{tabular}

Table 4. Eigenvector values for principal components (valores dos autovetores para os componentes principais). Campos dos Goytacazes, UENF, 2010.

\begin{tabular}{lccc}
\hline Principal component & Variance & Variance (\%) & Total variation (\%) \\
\hline CP01 & 6.4947399 & 49.9595374 & 49.9595374 \\
CP02 & 3.9489412 & 30.3764704 & 80.3360078 \\
CP03 & 1.2563151 & 9.6639622 & 89.99997 \\
CP04 & 0.8972736 & 6.9021046 & 96.9020746 \\
CP05 & 0.2582268 & 1.9863599 & 98.8884345 \\
CP06 & 0.1445035 & 1.1115655 & 100.0 \\
CP07 & 0.0 & 0.0 & 100.0 \\
CP08 & 0.0 & 0.0 & 100.0 \\
CP09 & 0.0 & 0.0 & 100.0 \\
CP10 & 0.0 & 0.0 & 100.0 \\
CP11 & 0.0 & 0.0 & 100.0 \\
CP12 & 0.0 & 0.0 & 100.0 \\
CP13 & 0.0 & 0.0 & 100.0 \\
\hline
\end{tabular}

$\mathrm{CP}=$ principal components (componentes principais).

which measure the degree of dissimilarity $\left(\mathrm{D}^{2}\right)$ between pairs of accessions, are listed in Table 3. The greatest distance was observed between UENF 1562 (Capsicum annuum var. annuum) and CNPH 3331 [Capsicum parvifolium $(\mathrm{D}=2.103866)]$; the smallest distance was observed between CNPH 3331 (Capsicum parvifolium) and UENF 1624 [Capsicum baccatum var. pendulum (D $=0.752432)]$. However, regardless of the maximum genetic divergence observed between the UENF 1562 and $\mathrm{CNPH}$ 3331 accessions, the recommendation for their use in hybridization breeding program should only be made after a careful agronomic evaluation.

The grouping was performed from the dissimilarity matrix through the hierarchical Ward's method, which like other hierarchical methods, generates a tree diagram or dendrogram. The first group was composed of the accession
The species from group II presented wider colpi than those in the species from group I.

Within group I, C. baccatum var. baccatum was the only species with a $\mathrm{P} / \mathrm{E}$ ratio, which is used to characterize the shape of the pollen grains, of less than $1 \mu \mathrm{m}$ and the smallest endoaperture width. These differences may have resulted in this species being placed more distantly from the others in the grouping.

A graphic representation of the scores (values assigned to the accessions based on all studied morphopollinic characters), and the similarity groups based on the first two main components can be observed in Figure 3. Through the PCA, we observed that the first two components (Table 4), explained more than $80 \%(80.33 \%)$ of the total variation and the same grouping pattern obtained by Ward's method was generated.

The grouping pattern observed in this study is in agreement with the classification of the Capsicum species in the gene complexes reported in the literature. According to this proposal, the Capsicum genus comprises three major groups: $C$. annuum, $C$. chinense and $C$. frutescens form the annuum complex; C. baccatum and C. pratermissum form the baccatum complex; and $C$. eximium, $C$. cardenasii and $C$. pubescens form the pubescens complex. These complexes were formed based on their morphological, cytogenetic and genetic aspects (Pickersgill, 1991).

The results obtained here are consistent with those obtained by Costa et al. (2009); they estimated the genetic divergence between 52 Capsicum spp. accessions via RAPD markers and morphoagronomic characters. These authors obtained a grouping pattern that corresponded with the Capsicum spp. classification in gene complexes with two large groups, one of them formed by the accessions of $C$. baccatum and another formed by the accessions of $C$. chinense, C. frutescens and C. annuum. The inter-specific breeding between species of the same gene complex is regarded as possible, and within the $C$. annuum complex, many inter-specific hybrids have been obtained successfully (Pickersgill, 1997). 

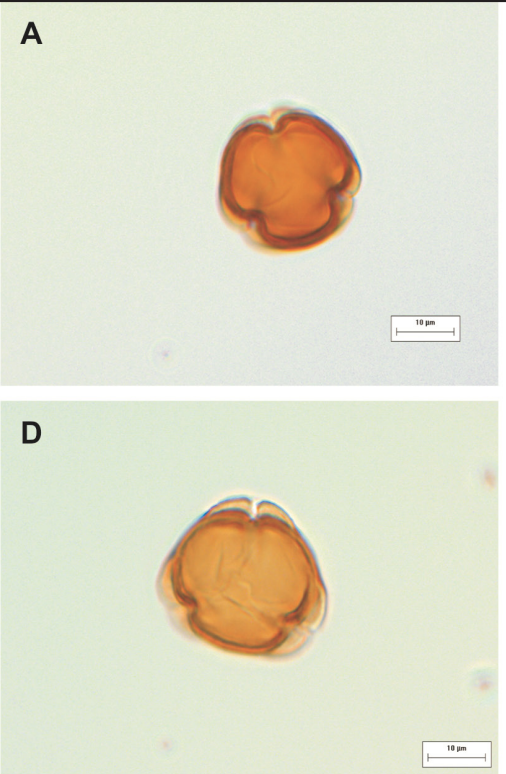

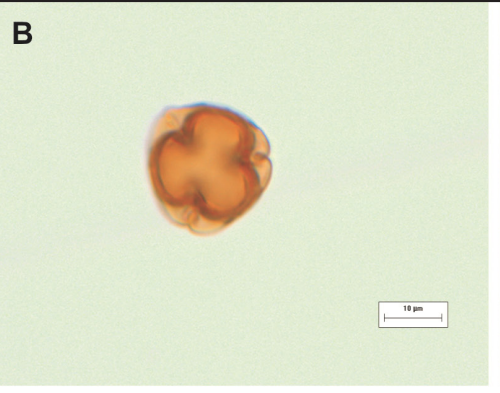

E

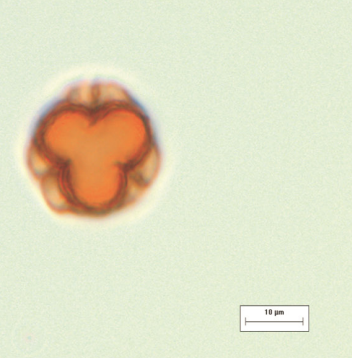

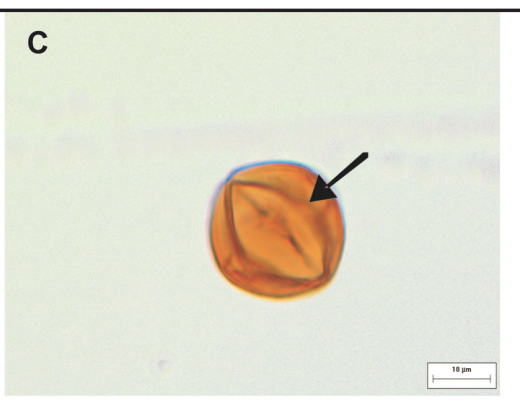

$\mathbf{F}$

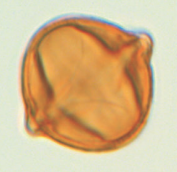

Figure 1. Light micrographs of pollen grains of Capsicum. A) polar view in C. parvifolium (CNPH 3331); B) polar view of C. chinense (UENF 1785); C) equatorial view of C. baccatum var. pendulum (UENF 1624), showing colpus (arrow); D) equatorial view of C. baccatum var. baccatum (UENF 1495) showing sub-circular amb; E) equatorial view in C. annuum var. annuum (UENF 1562) showing triangular amb; F) equatorial view in C. frutescens (UENF 1636) (microscopia de ótica dos grãos de pólen de Capsicum. A) vista polar em $C$. parvifolium (CNPH 3331); B) vista polar de C. chinense (UENF 1785); C) vista equatorial de C. baccatum var. pendulum (UENF 1624), mostrando colpus (seta); D) vista equatorial de C. baccatum var. baccatum (UENF 1495) mostrando âmbito sub-circular; E) vista equatorial em C. annuum var. annuum (UENF 1562) mostrando âmbito triangular; F) vista equatorial em C. frutescens (UENF 1636)). Campos dos Goytacazes, UENF, 2010.

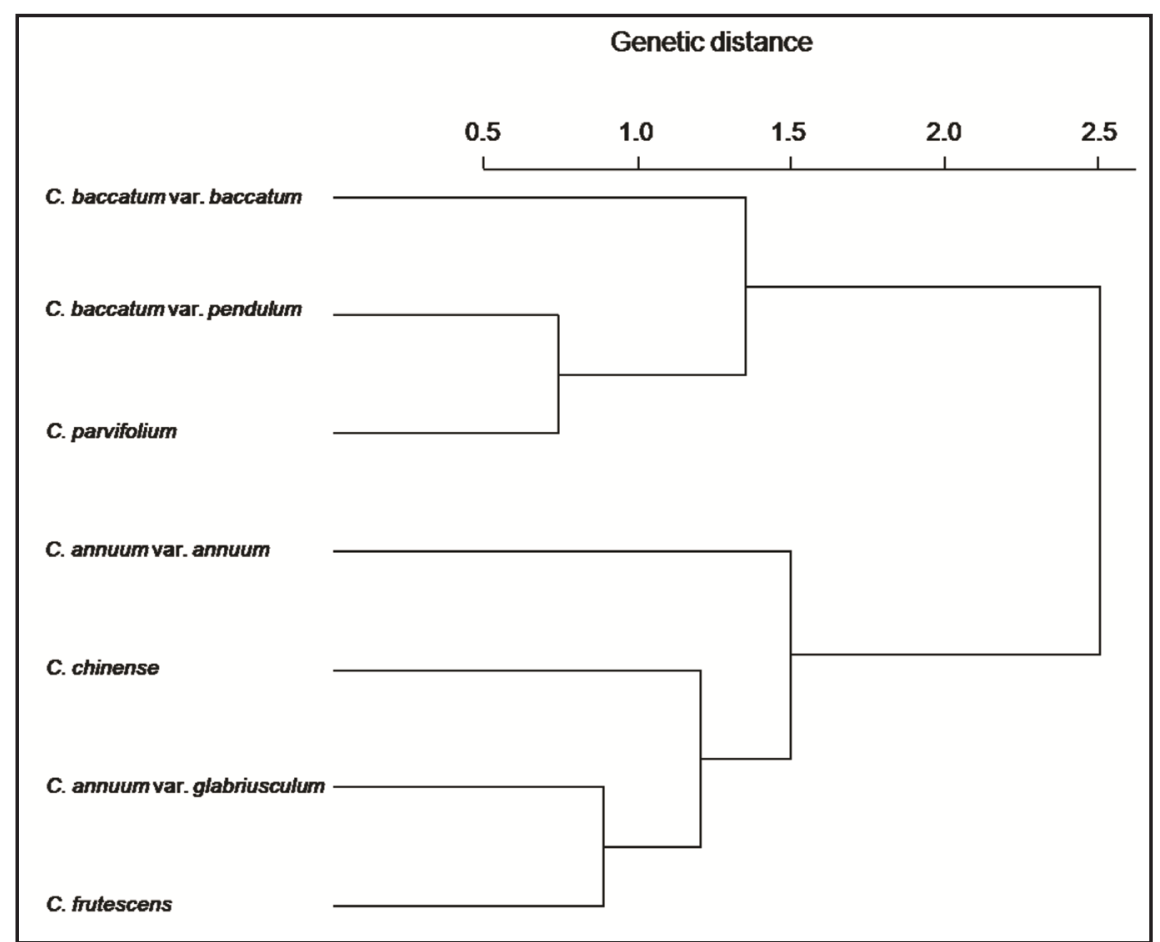

Figure 2. Dendrogram obtained through the hierarchical Ward's method, based on 13 pollinic characteristics (dendrograma obtido através do método hierárquico de Ward, com base em 13 características polínicas). Campos dos Goytacazes, UENF, 2010.

The species $C$. annuum and $C$. baccatum belong to different gene complexes, and according to Pickersgill
(1991) an evident genetic distance exists between these species, the hybrid of this cross has pollen grains with reduced viability and hence a low likelihood of seed formation.

In the present study, domesticated and semi-domesticated species were classified based on the morphopollinic data and according to gene complexes. The wild species $C$. parvifolium is more closely related to the species in the $C$. baccatum complex than the species in the $C$. annuum complex; so, it can be classified as member of $C$. baccatum complex.

According to Iwanami \& Yoshio (1988), in the scope of morphological characterization, the analysis of pollenrelated descriptors serves to separate related species, because characteristics such as shape, number of apertures, position and type of apertures, and ornamentation of the exine, among others, are genetically determined.

In the studied Capsicum accessions, the variable that most contributed to the accumulated variation was the width of the pore, and the variable that least contributed to the accumulated variation was the polar axis in the equatorial view. The accumulated variation in the first two components, which was $80.34 \%$ in the analysis using all descriptors, fell to 


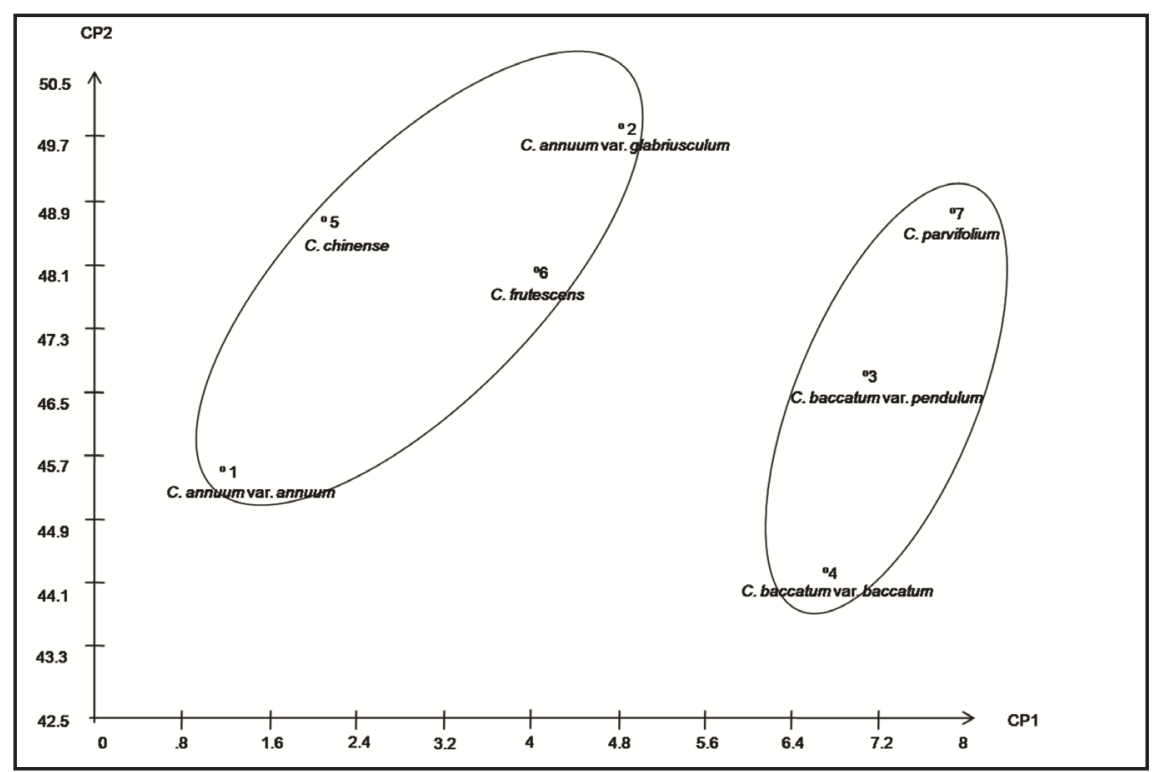

Figure 3. Graphic dispersion of the accessions based on the first two principal components (dispersão gráfica dos acessos com base nos dois primeiros componentes principais). Campos dos Goytacazes, UENF, 2010.

$79 \%$ without the use of the polar axis descriptor in the equatorial view, thereby confirming the low contribution of this descriptor to the accumulated variation. Since it is not discriminant, we suggest that the polar axis in the equatorial view may be discarded in future studies of genetic divergence based on pollen characteristics.

\section{ACKNOWLEDGMENTS}

The authors thank to the Embrapa Hortaliças for the donation of CNPH3331 accession. They also thank to UENF for the scholarship.

\section{REFERENCES}

AL-WADI HM; LASHIN GMA. 2007. Palynological and cytological characters of three species of genus Solanum (Family: Solanaceae) from Saudi Arabia. Journal of Biological Sciences 7: 626-631.

BARTH OM; DUARTE SG. 2008. Morfologia polínica de espécies arbóreas de Solanaceae do Estado de Santa Catarina, Brasil. Hoehnea 35: 379-386.

BARTH OM; MELHEM TS. 1988. Glossário Ilustrado de Palinologia. (Campinas: Editora da Universidade Estadual de Campinas. 75 p.

BOSLAND PW; VOTAVA EJ. 2012. Peppers: vegetable and spice Capsicums. Wallingford: CAB International. 248 p.
COSTA FR; PEREIRA TNS; SUDRÉ CP; RODRIGUES R. 2009 Marcadores RAPD e caracteres morfoagronômicos na determinação da diversidade genética entre acessos de pimentas e pimentões. Ciência Rural 39: 696-704.

CRUZ CD. 2006. Programa Genes: aplicativo computacional em genética e estatística Available at http://www.ufv.br/dbg/genes/ genes.htm. and Plant Taxonomy. An Introduction to Palynology, I. Angiosperms. New York: Hafner. $553 \mathrm{p}$

ERDTMAN G. 1960. The acetolysis method. A revised description. Svensk Botanisk Tidskrift 54: 561-564.

ERDTMAN G. 1952. Pollen morphology and plant taxonomy Angiosperms. Stockholm: Almqvist \& Wiksell. $539 \mathrm{p}$

FRANKLIM CPRB; ESTEVES VG. 2008. Palinologia de espécies de Solanum L. (Solanaceae A. Juss.) ocorrentes nas restingas do estado do Rio de Janeiro, Brasil. Acta Botanica Brasilica 22: 782-793.

HE G; PRAKASH CS; JARRET RL. 1995. Analysis of genetic diversity in a sweetpotato (Ipomoea batatas) germplasm collection using DNA amplification fingerprinting. Genome 38: 938-945.

IWANAMI YS; YOSHIO Y. 1988. Pollen: Illustrations and scanning of electron micrographs. Tokyo: Kodans \& SpringerVerlag. $198 \mathrm{p}$

JUDD WS; CAMPBELL CS; KELLOG EA; STEVENS PF; DONOGHUE MJ. 2007. Plant systematics: a phylogenetic approach. Sunderland: Sinauer Associates Inc. 620 p.

KUMAR AO; PANDA RC; RAO KGR; RAMANUJAM CGK. 1986. Pollen
ERDTMAN G. 1986. Pollen Morphology morphological studies in Capsicum: 1 . Species and varieties. Geophytology 16: 166-175.

LASHIN GMA. 2012. Ultrastructure and pollen morphology significance of some species of Solanum (Solanaceae). Egyptian Journal of Botany 141-156.

MARTINS KC; PEREIRA TNS; SOUZA SAM; COSTA FR. 2010. Meiose e Viabilidade Polínica em acessos de Capsicum annuum e Capsicum baccatum. Ciência Rural 40: 1746-1751.

MOSCONE EA; SCALDAFERRO MA; GRABIELE M; CECCHINI NM; GARCÍA YS; JARRET R; DAVIÑA JR; DUCASSE DA; BARBOZA GE; EHRENDORFER F. 2007. The evolution of chili peppers (Capsicum - Solanaceae): a cytogenetic perspective. Acta Horticulturae 745: 137-169.

PERVEEN A; QAISER M. 2007. Pollen morphology of family Solanaceae from Pakistan. Pakistan Journal of Botany 39: 2243-2256.

PICKERSGILL B. 1997. Genetic resources and breeding of Capsicum spp., Euphytica 96: 129-133.

PICKERSGILL B. 1991. Cytogenetics and evolution of Capsicum L. In: TSUCHIYA T \& GUPTA PK (eds) Chromosome engineering in plants: genetics, breeding, evolution, Part B. Elsevier: Amsterdam. p. 139-160.

PUNT W; BLACKMORE S; NILSSON S; LE THOMAS A. 2007. Glossary of pollen and spore terminology. Review of Palaeobotany and Palynology 143: 1-81.

RAGHUVANSHI RK. 1977. Palynological studies in Capsicum L. Journal of Palynology 12: 81-86.

RIVA EM; RODRIGUES R; SUDRÉ CP; PEREIRA MG; VIANA AP; AMARAL JÚNIOR AT. 2007. Obtaining pepper F2:3 lines with resistance to the bacterial spot using the pedigree method. Horticultura Brasileira 25: 567-571.

RR Foundation for Statistical Computing. 2004. Development Core Team. $R^{\prime}$ a language and environment for statistical computing. Available at: http://www.R-project.org.

SALGADO-LABOURIAU ML. 1973. Contribuição à palinologia dos cerrados. Rio de Janeiro: Academia Brasileira de Ciências. 291 p.

SOUZA SAM; MARTINS KC; PEREIRA TNS. 2011. Polimorfismo cromossômico em Capsicum chinense Jacq. Ciência Rural 41: 1777-1783.

STUESSY TF. 2009. Plant taxonomy: the systematic evaluation of comparative data. Columbia University Press. 568 p.

SUDRÉ CP; RODRIGUES R; RIVA EM; KARASAWA M; AMARAL JÚNIOR AT. 2005. Divergência genética entre acessos de pimenta e pimentão utilizando técnicas multivariadas. Horticultura brasileira 23: 22-27.

WILLARD DA; BERNHARDT CE; WEIMER L; COOPER SR; GAMEZ D; JENSEN J. 2004. Atlas of pollen and spores of the Florida everglades. Palynology 28: 175-227. 